\title{
Histological Alterations in Gill, Liver and Kidney of Rainbow Trout following Fungal Infection
}

\author{
Debajit Sarma*, Vimal Kohli, Sarika Singh Kushwaha, Jyoti Pandey, S. K. Mallik, Neetu Shahi, \\ Partha Das, S. K. Srivastava, Vineeta Joshi and M. S. Akhtar
}

Directorate of Coldwater Fisheries Research (Indian Council of Agriculture Research), Bhimtal, Nainital, (Uttarakhand), India -263136

\begin{abstract}
Histomorphological changes were observed to assess the effect of fungus on gill, liver and kidney of Rainbow trout (Oncorhynchus mykiss). The most frequent histological changes detected in the gills included hypertrophy, hyperplasia and fusion of secondary lamellae. Other lesions found were vacuolization, blood congestion, and increased melano-macrophage (MM) in liver. Shrinkage of glomerulus, increased Bowmen's space, increased MM and hematopoietic tissue were observed in the kidney.
\end{abstract}

Keywords: Histomorphology, Rainbow trout, Fungal infection.

\section{Introduction}

The rainbow trout (Oncorhynchus mykiss) is a commercially important coldwater fish which is generally cultured in Indian upland region. The colonization of aquatic fungi in teleost fish is a severe problem affecting both wild and cultured fish population. However, the fungal infection is more abundant in the captive environment which adversely affects fish industry. An external fungal infection cause lesions, subsequently become enlarge and may lead death (Hoffman, 1963). Stress, physical injury, malnutrition and poor water quality increase the susceptibility of fungal infections (Roth, 1972; Piper et al., 1983). Gill, kidney and liver are responsible for vital functions such as respiration, excretion, erythropoiesis, regulating blood pressure and the accumulation and biotransformation of xenobiotics in the fish (Hole, 1992; Gernhofer et al., 2001; Aguis and Robert, 2003). The alterations found in these organs are easier to identify than functional ones (Fanta et al., 2003), and serveas warning signs of damage to animal health (Hinton and Laurén, 1990). Hence, the study of tissue deformities in respect to fungal infection which is commonly encountered in cold water aquaculture needs to be studied in order to attain maximum yield. Keeping this in mind, the present study was carried out in order to understand and describe the degree of histological alterations in gill, kidney and liver following fungal infection.

\section{Materials and Methods}

Six adult live specimens (fungal infected as well as healthy rainbow trout) were collected from Experiment Field Centre of Directorate of Cold Water Fisheries Research (ICAR), Champawat $\left(80^{\circ} 07^{\prime} \mathrm{N}, 29^{\circ} 30^{\prime} \mathrm{N}\right.$, and $\left.1620 \mathrm{msl}\right)$, Uttarakhand, India. After, being taken to the laboratory, fishes were dissected and the samples of gill, liver, kidney were fixed in Bouin's fixative for 24 hours. After fixation, the samples were washed in water, dehydrated in graded ethanol solutions, cleared in xylene and embedded in paraffin. Paraffin blocks were sectioned 5-6 $\mu \mathrm{m}$ thick on a microtome (Microm HM $340 \mathrm{E})$. The resulted sections were dewaxed and stained for histological purposes with haematoxylin and eosin ( $\mathrm{H}$ and $\mathrm{E}$ ) (Delafield, 1885). Histological sections were examined 
through light microscope (Magnus MLX-DX) equipped with digital camera (Olympus E-420) at the magnification of $100 x$ to $1000 x$.

\section{Results and Discussion}

\section{Gills}

The histological analysis of healthy fish gill indicated the primary gill lamella $(P L)$ contains a centrally placed rod like axis (CA) with a row of secondary gill lamellae (SL) on both side of it. The secondary lamellae attached at their base with the primary lamellae free at their distal ends and covered by highly vascularized thin epithelial cells (EC). Inter lamellar region (ILR) is present between the two adjacent secondary lamella (Fig. 1a and 1b). However, histological observations in fungal infected rainbow trout clearly indicated the cytoarchitectural dis- tortion of gills with marked, hypertrophy and hyperplasia of pillar and epithelial cells resulting in the fusion of secondary lamellae. Epithelium of secondary lamellae showed cloudy swelling. Inter lamellar region was reduced or completely absent in some places between the secondary lamella. Extensive disruption of primary lamella was also observed. More severe lesions were observed in the gill with hemorrhage due torupture of lamellar epithelium (Fig. 1c and 1d).

The gills of fish are multi functional organs as they participate in respiration, osmoregulation, acid-base balance, excretion. They Remain in close contact with the external environment, which also makes them extremely sensitive to changes in the quality of the water. They are considered the primary target of the contaminants (Poleksic and Mitrovic, 1994; Mazon et al., 2002; Fernandes and Mazon, 2003; Au,
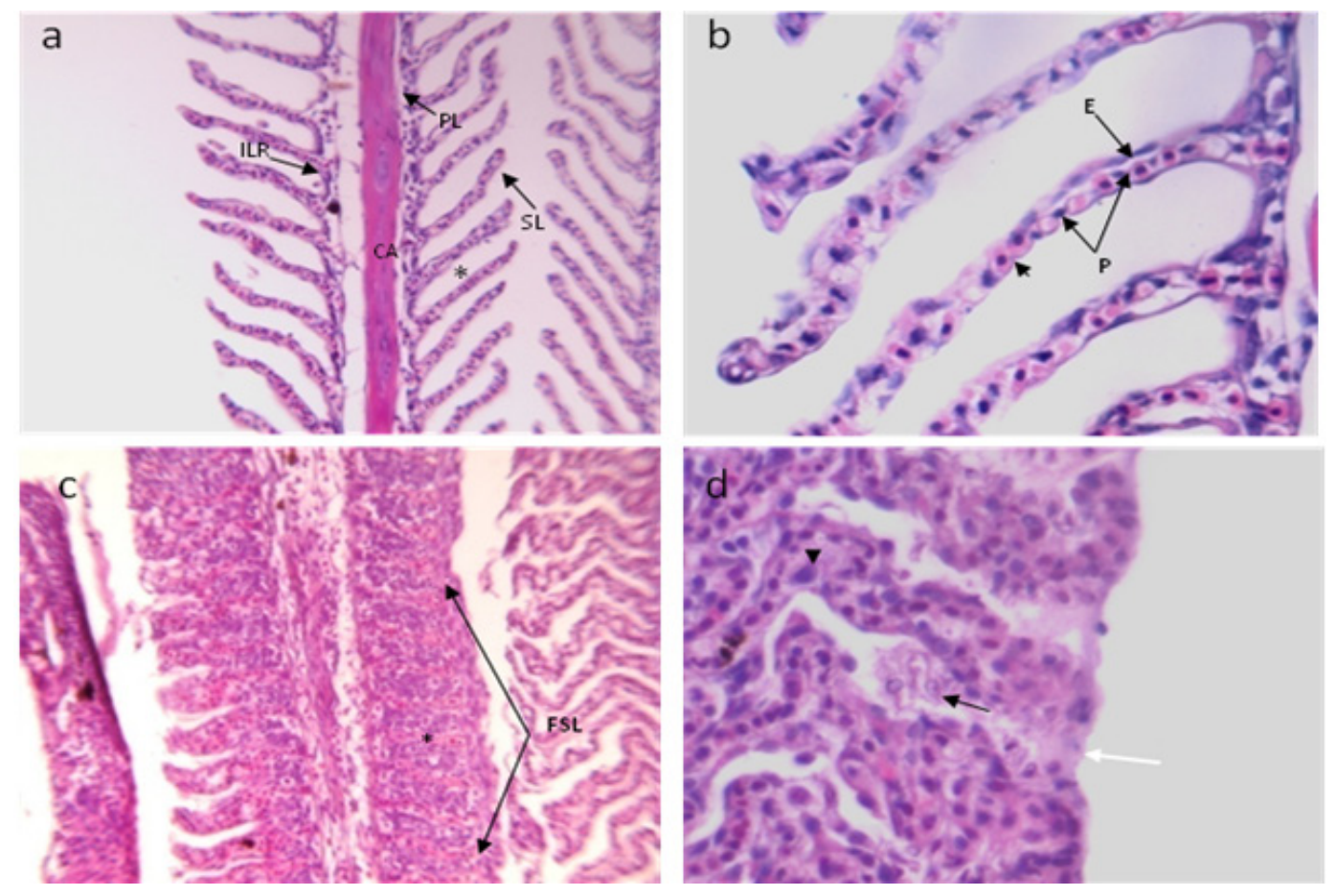

Fig. 1. Photomicrographs of the gill of $O$. mykiss $(a, b)$ normal gill showing the primary lamella $(P L)$, secondary lamella $(S L)$, central axis $(C A)$, inter lamellar region (ILR), water channel $\left(^{*}\right)$, pillar cell $(P)$, epithelial cell $(E)$, erythrocytes (short arrow); (c, d) fungal infected gill showing hyperplasia in secondary lamellae $\left({ }^{*}\right)$, completely fusion of secondary lamella (FSL), hypertrophy (arrowhead), rupture of epithelium (black arrow), cloudy swelling (white arrow). $\mathrm{H}$ and $\mathrm{E} 400 \mathrm{X}$ $(a, c), 1000 X(b, d)$. 
2004). According to the observations in the present study, fungi cause major histomorphological alterations in the gill of $O$. mykiss like hyperplasia, hypertrophy, completely fusion of secondary lamellae are examples of defense mechanisms. These may result in the increase of distance between the external environment and blood which act as a barrier. Similar observation were also seen by other workers (Mallatt, 1985; Hinton and Lauren, 1990; Poleksic and Mitrovic, 1994; Fernandes and Mazon, 2003). On the other hand, fusion of secondary lamella decreased inter lamellar distance, results in reduction in the diffusion conductance of the gills to respiratory gases (Greco et al., 1995; Perry et al., 1996), leading to impaired oxygen uptake by gills. The results of the present study also depict the same.

\section{Liver}

In general, the surface of liver is enclosed by serous membrane and connective tissue extends inward into parenchyma. The histological analysis of healthy liver tissue of rainbow trout indicates that the hepatocytes are rounded polygonal cells with spherical nucleus, arranged in distinct tubules. Tubules contain 5 to 7 hepatocytes arranged radially around with their apices surrounding a billary lumen. The basal aspects of hepatocytes faced the perisinusoidal space. Sinusoids appeared in the intersticial between hepatic tubules in our present experiment (Fig. 2a).

However, it was observed in the present study that fungal infection causes discrete pathological changes in the liver tissue of fish. These
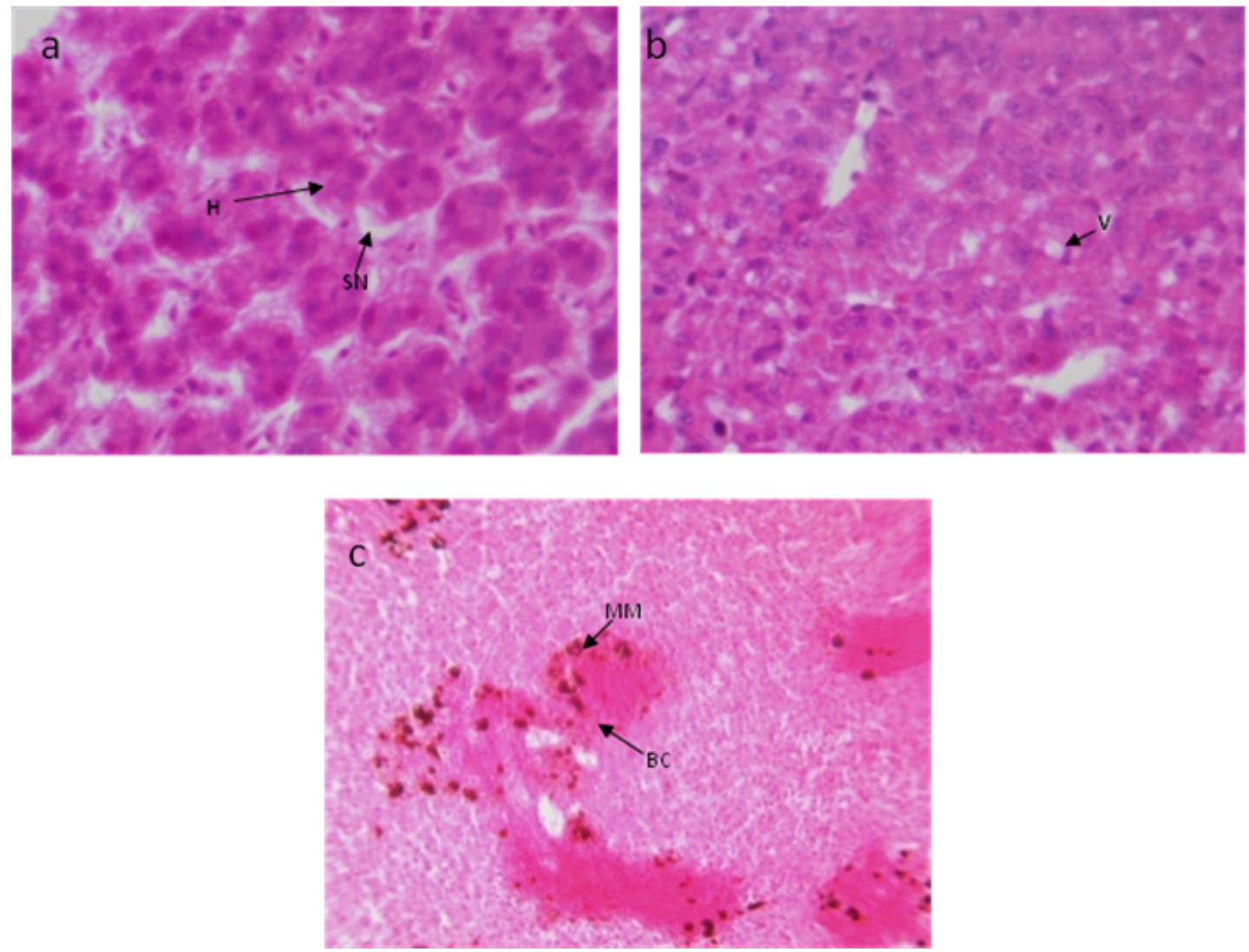

Fig. 2. Photomicrographs of the liver of O. mykiss (a) normal liver showing the hepatocytes $(H)$, sinusoids (SN); (b,c) fungal infected liver showing vacuole formation (V), melanomacrophage (MM), blood congestion (BC). H and E 1000X (a), 400X (b), 100X (c). 
changes include blood congestion, increased accumulation of melano-macrophage and vacuole formation. Vacuolization observed are zones of total cell degeneration (Fig. 2b and 2c). Similar changes were also observed in the liver after exposure of various contaminants (Masud et al., 2001, 2003, Butchiram., 2009). Melano-macrophage aggregation at the site of blood congestion as these develop in association with chronic inflammatory lesions (Aguius and Robert, 2003). The result of our study also revealed the same.

\section{Kidney}

The histological analysis of kidney of healthyrainbow trout consists of the functional unit called nephrone which contains glomerulus, Bowman's capsule, proximal, distal and collecting tubules. The hematopoietic tissue present between the tubules. Occasionally, Melanomacrophage centers located in hematopoietic tissue (Fig. 3a and 3b).

However, histological analysis of infected tissue indicated degeneration of glomerular tuft. Bowmen's space of glomeruli became increased (Fig. 3c). Similar alterations in the kidney have also been reported in the fishes exposed to various compound such as zinc, lead, copper (Al-Zahaby et al., 1998), trichlorfon (Marcelo etal., 2002), nitrate (lqbal etal., 2004), dimethoate (Singh, 2012), ethylenediaminetetraacetic acid (Ghorashi et al., 2013). It is known that
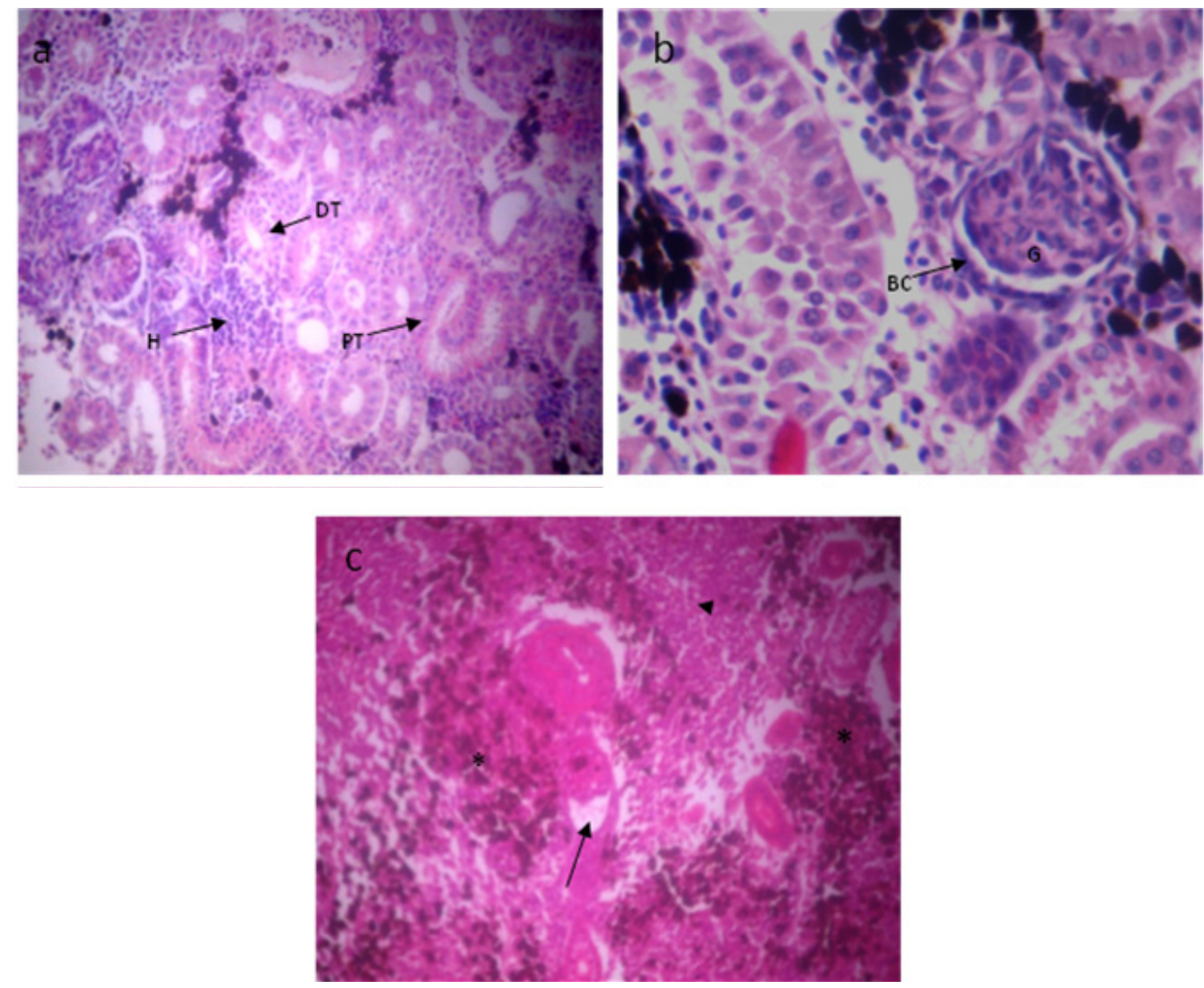

Fig. 3. Photomicrographs of the kidney of $O$. mykiss $(a, b)$ normal kidney showing the proximal tubule (PT), distal tubule (DT), hematopoeitic tissue $(H)$, bowmen's capsule (BC), glomerulus $(G)$; (c) fungal infected kidney showing aggregation of melanomacrophase $\left({ }^{*}\right)$, increased Bowmen's space (arrow), increased hematopoeitic tissue (arrow head). H and E 400X (a,c), 1000x (c). 
maleno-macrophage contained macrophages and a variety of pigments including melanins, lipofuscin, ceroid and hemosiderin (Couillard et al., 1999). The accumulation of melanomacrophage was more apparent in fungal infected kidney tissue as observed in our study (Fig. 3c). Density of melanomacrophage increased in the condition of environmental stress, in the presence of cachectic disease and also develops in association with chronic inflammatory lesions elsewhere in the body (Vijayan and Leatherland, 1988; Agius and Roberts, 2003). Handy and Penrice (1993) also observed melano-macrophage in the kidney of trout (Salmotrutta) and Tilapia (Oreochromismossambicus) exposed to mercuric chloride. Hematopoietic tissue formed a supporting matrix for the nephrons (Hickman and Trump, 1969). An extreme enhancement was also evident in hematopoietic tissue and it spread over large area, which may be an effort to provide additional support to degenerating nephrons.

The result of the present study revealed that histology may be an effective tool in describing the histomorphological alterations in the selective tissue of rainbow trout having fungal infection. As a result, the current effort will certainly help to understand the severity of fungal infection in the production system and thereby to take successful strategies to maximize the yield in the cold water aquaculture of rainbow trout.

\section{Acknowledgements}

The authors like to thank Dr. S. Chandra, Sr. Scientist and Dr. S. K. Gupta, Scientist of Experimental Field Centre of DCFR, Champawat for helping in sample collection.

\section{References}

Agius, C. and Robert, R.J. (2003) Melano-macrophage centers and their role in fish pathology. J. Fish Dis., 26, 499-509.

Al-Zahaby, A.S, Hemmaid, K.Z., Carnal, A.M and Ghoncmy (1998) The pollutant effects ofcopper, zinc and lead on the histological patterns of fish kidney. Egypt J. Aquat. Biol. Fisheries., 2, 15-41.
Au, D.W.T. (2004) The application of histocytopathological biomarkers in marinepollution monitoring: a review. Mar. Poll. Bull., 48, 817-834.

Butchiram, M. S., Tilak, K. S. and Raju, P. W. (2009) Studies on Histopathological changes inthe gill, liver and kidney of Channapunctatus (Bloch) exposed to Alachlor. J. Environ. Biol., 30, 303-306.

Couillard, C.M., Williams, P.J., Courtenay, S.C. and Rawn, G.P. (1999) Histopathologicalevaluation of Atlantic tomcod (Microgadustomcod) collected at estuarine sites receiving pulp and paper mill effluent. Aquat.Toxicol., 44, 263-278.

Delafield, J., cited by Prudden, J.M.(1885) Zeitschriftfürwissenschaftliche. Mikroskopie fürmikroskopische Technik, 2, 228.

Fanta, E., Rios, F. S., Romão, S., Vianna, A. C. C. and Freiberger, S. (2003) Histopathology of the fish Corydoraspaleatuscontaminated with sublethal levels of organophosphorus in water and food. Ecotoxicol. Environ Saf, 54, 119-130.

Fernandes, M. N. and Mazon, A. F. (2003) Environmental pollution and fish gill morphology. In: Val, A. L. \& B. G. Kapoor (Eds.). Fish adaptations. Enfield, Science Publishers, pp. 203-231.

Gernhofer, M., Pawet, M., Schramm, M., Müller, E. and Triebskorn, R. (2001) Ultrastructural biomarkers as tools to characterize the health status of fish in contaminated streams. J. Aquat. Ecosyst., Stress and Recov., 8, 241-260.

Ghorashi, S., Shajeei, H and Vaezi, G. (2013) Histopathological studies on kidneys and gills of exposed to sub lethal concentration of ethylenediaminetetraacetic acid (EDTA). Global Veterinaria., 2, 121-127.

Greco, A.M., Gilmour, K.M., Fenwick, J.C. and Perry, S.F. (1995) The effects of soft water acclimation on respiratory gas transfer in the rainbow trout, On-corhynchus mykiss. J. Exp. Biol., 198, 2557-2567.

Handy, R.D. and Penrice, W.S. (1993) The influence of high oral doses ofmercuric chloride onorgan toxicant concentrations and histopathology in rainbow trout, Oncorhynchus mykiss. Comp. Biochem. Physiol. (C)., (C), 106, 717-724.

Hickman, C.P. and Trump, B.J. (1969) The kidney.In: "Fish Physiology" W.S., Hoar and D.J. Randall (Eds.) Academic Press Inc. NewYork, NY and London, 1, pp. 91-239.

Hinton, D. E. and Laurén, D. J. (1990) Liver structural alterations accompanying chronic toxicity in fishes: potentioal biomarkers of exposure. In: McCarthy, J.F. and Shugart, L.R. (Eds.). Biomark Environ Contam. Boca Raton, Lewis Publishers, pp.51-65. 
Hoffman, G.L. (1963) Parasites of freshwater fish. I. Fungi (Saprolegnia and relatives) of fish and fish eggs. U.S., Leaflet, 21,6.

Hole, J.W. (1992) Essentials of human anatomy and physiology. 4th ed. Wm. C. Brown Publishers, Dubuque, pp. 745-749.

Iqbal, F., Qureshi, I.Z. and Ali, M. (2004) Histopathological changes in the kidneyof common carp, Cprinuscarpio, following nitrate exposure. J. Res. (Science)., 4, 411-418.

Marcelo, Leite, da Veiga, Edson, de Lara, Rodrigues, Fabio Juliano Pacheco and Maria José Tavares Ranzani-Paiva (2002) Histopathological Changes in the Kidney Tissue of Prochiloduslineatus Valenciennes, 1836 (Characiformes, Prochilodontidae) Induced by sub lethal concentration of trichlorfon exposure. Braz Arch Biol Technol., 45, 171-175.

Mallatt, J. (1985) Fish gill structural changes induced by toxicants and other irritants: a statistical review. Canadian J. Fish. Aquat. Sci., 42, 630-648.

Masud, S., Singh, I.J. and Ram, R.N. (2003) First maturity and related changes in female Cyprinuscarpioafter a long term exposure to mercurial compound. J. Ecophysiol. Occup. Hith., 3, 1-14.

Masud, S, Singh I.J. and Ram, R.N. (2001) Testicular recrudescence and related changes in Cyprinuscarpio after a long term exposure to mercurial compound. J. Ecophysiol. Occup. HIth., 1, 109-120.

Mazon, A. F., Pinheiro, G. H. D and Fernandes, M. N. (2002) Hematological and physiological changes induced by short-term exposure to copper in the freshwater fish, Prochilodusscrofa. Brazilian $\mathrm{J}$. Biol., 62, 621-631.

Perry, S.F., Reid, S.G., Wankiewicz, E., lyer, V. and Gilmour,K.M. (1996) Physiological responses of Rainbow trout (Oncorhynchus mykiss) to prolonged exposure to soft water. Physiol. Zool., 69, 1419-1441.

Piper, R.G., McElwain, I.B., Orme, L.E., McCraren, J.P., Fowler, L.G. and Leonard, J.R. (1983) Fish Hatchery Management. United States Department of the Interior. Fish and Wildlife Service, Washington D.C

Poleksic, V. and Mitrovic- Tutundzic, V. (1994) Fish gills as a monitor of sub lethal and chronic effects of pollution. In: Muller, R. and R. Lloyd (Eds.). Sub lethal and chronic effects of pollutants on freshwater fish. Oxford, Fishing News Books, pp. 339-352.

Roberts, R.J. (1989) Fish Pathology, $2^{\text {nd }}$ edition. BailliereTindall. Philadelphia, A.

Roth, R.R. (1972) Some factors contributing to the development of fungus infection in freshwater fish. $J$ Wildlife Diseases, 8, 24-28.

Singh, R. (2012) Histopathological alterations in the kidney of Cyprinuscarpioafter exposure to dimethoate (EC 30\%). Indi. J. Sci. Res., 1, 127-131.

Vijayanan, M.M. and Leatherland, J.F. (1988) Effects of stocking density on the growth and stress response in brook char, Salvelinus fontinalis. Aquaculture., 75, 159-170. 